\title{
Implementation of a Multiregion Hybridization Assay to Characterize HIV-1 Strains Detected among Injecting Drug Users in Manipur, India
}

\author{
Roni Sarkar $^{\text {a Satarupa Sengupta }}{ }^{a}$ Ranajoy Mullick ${ }^{a} \quad$ N. Brajachand Singh ${ }^{b}$ \\ Kamalesh Sarkar ${ }^{a}$ Sekhar Chakrabarti ${ }^{a}$

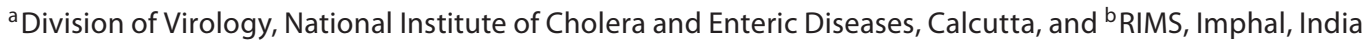

\section{Key Words}

Drug users • Heteroduplex mobility assay · HIV strains •

Hybridization • Multiregion hybridization assay

\begin{abstract}
We have implemented the latest technology of a multiregion hybridization assay (MHAbce, version 2) for the molecular characterization of HIV-1 among injecting drug users (IDUs) of Manipur, India. This study provides a more detailed analysis on the basis of probes designed from eight different genomic regions of HIV-1, to achieve a clear picture of HIV-1 genomic diversity in Manipur. Out of 30 samples, 15 were found to be of subtype $C, 1$ of subtype B, 5 with dual-probe reactivity, 8 with multigenomic recombination pattern and 1 sample showed both dual-probe reactivity and multigenomic variations. In contrast, the heteroduplex mobility assay (HMA) with respect to gag and env genes revealed 21 samples to be of subtype $C$ (gag C/env $C$ ), 3 samples of subtype $B$ (gag $B /$ env $B$ ) and 6 samples of $B / C$ recombinants (gag $\mathrm{C} /$ env $\mathrm{B}$ ). MHAbce illustrates the occurrence of inter- and intragenomic variants and dual infection in an IDU population from India. It also indicates the possibility of the presence of new circulating recombinant forms of HIV-1 strains, which might have been difficult to trace by HMA alone.
\end{abstract}

Copyright ๑ 2009 S. Karger AG, Basel

\section{KARGER}

Fax +4161306 1234 E-Mail karger@karger.ch www.karger.com (c) 2009 S. Karger AG, Basel

0300-5526/09/0524-0175\$26.00/0

Accessible online at:

www.karger.com/int
Manipur, one of the states in the northeastern region of India bordering Myanmar, is very close to the 'Golden Triangle' (composed of northern Thailand, eastern Myanmar and western Laos). These regions are the world's leading opium- and heroin-producing area. Reported cases of HIV-infected individuals are quite high in Manipur $(>1 \%$ HIV positivity among women in antenatal clinics and $>5 \%$ among patients in sexually transmitted diseases clinics) [1] due to international drug trafficking and sharing of contaminated needles and syringes $[2,3]$. As reported earlier, the number of injecting drug users (IDUs) estimated all over the world is 13.2 million $(0.3 \%$ of the estimated 4 billion adult population), the majority of which (10.3 million) live in developing countries [4].

The presence of dual-subtype infection, intersubtype recombination between subtype $C$ and Thai $B$, has been reported in Manipur [5,7] using a heteroduplex mobility assay (HMA) based on gag (p24-p7) and env (C2-V3) regions. In HMA, amplicons of gag and env genomic regions from an unknown subtype were mixed individually with amplicons of different known (reference) subtypes separately followed by rapid denaturation and renaturation to form heteroduplexes. The heteroduplex formed between the unknown sample and its closest subtype exhibits fastest mobility in polyacrylamide gel. As HMA is restricted to two genomic regions only, the real scenario of genetic diversity of HIV-1 cannot be ascertained. A multiregion hybridization assay (MHA) has

National Institute of Cholera and Enteric Diseases, P-33, CIT Road, Scheme-XM

Beliaghata, Calcutta 700010 (India)

Tel. +91 332370 1176, Fax +913323705066

E-Mail drsekharchakrabarti@yahoo.co.in 
Fig. 1. The probes for the MHAbce v. 2 assay were designed as shown in black circles within the HIV-1 genome covering all the genes. The $\mathrm{p} 24-\mathrm{p} 7$ region in the gag gene and the $\mathrm{C} 2-\mathrm{V} 3$ region in the env gene used for HMA is shown in gray rectangles.

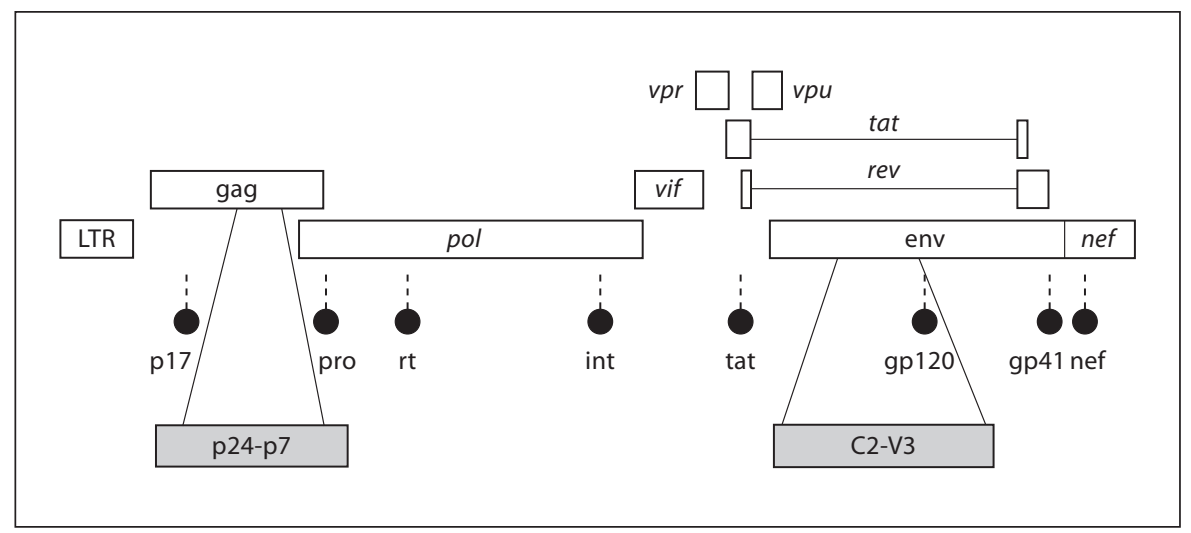

been developed based on real-time PCR using subtypespecific TaqMan probes within different regions of the HIV-1 genome [8-11]. This technology is a powerful tool in tracking new circulating recombinant HIV-1 strains.

Here we report for the first time the implementation of MHAbce (version 2; v.2) among the IDU population from Manipur (India) to characterize HIV-1 strains with improved scope and clarity.

A total of 62 blood samples were collected from IDUs in Manipur after obtaining their informed consent. HIV1 testing was done by ELISA (Immunogenetics, Zwijndrecht Belgium) followed by the TRIDOT assay according to the policy of the country's National AIDS Control Program. Thirty samples were found to be HIV-1 seropositive and were used for genotyping studies. HMA was performed with respect to $500 \mathrm{bp}$ of env (C2-V3) and 460 bp of gag (p24-p7) genomic regions (fig. 1) and also confirmed by DNA sequencing. Results of HMA revealed that 21 samples were of subtype $\mathrm{C}$ (gag C/env C), 3 samples of subtype B (gag B/env B) and 6 samples of B/C (gag C/env B) recombinants (table 1).

In MHAbce v.2, multiple short fragments were amplified throughout the HIV-1 genome (fig. 1) to assess the hybridization of clade-specific fluorescent probes in realtime PCR. The viral RNA was extracted from plasma using a viral RNA mini kit (Qiagen $\mathrm{GmbH}$, Hilden, Germany). The primers and probes (Applied Biosystems, Foster City, Calif., USA) were used with respect to subtype $\mathrm{B}, \mathrm{C}$ and $\mathrm{AE}[12]$. The genomic regions within $p 17$, protease (pro), reverse transcriptase ( $r t$ ), integrase (int), first exon of tat (tat), C3 in gp120 (gp120), and gp41/nef were amplified in separate first-round PCR using cDNA synthesized by reverse transcriptase PCR from viral RNA. The second round real-time PCR was performed in a final volume of $25 \mu \mathrm{l}$ with TaqMan $2 \times$ Universal
PCR Master Mix (Applied Biosystems) including an aliquot of each amplicon from first-round PCR products distributed in separate sets of second-round PCRs with subtype-specific probes for (p17, pro, rt, int, tat, gp120, gp41 and nef) gene fragments. The gp120 probes were labelled with reporter dye 6-carboxytetramethylrhodamine and Black Hole Quencher at 5'- and 3'-ends, respectively, whereas all the other probes were labelled with 6carboxy fluorescein (FAM) at the $5^{\prime}$-end as reporter dye and with Black Hole Quencher at the 3 '-end. During the amplification, emission of fluorescence started due to the breakage of linkage between reporter and quencher. The fluorescence was measured and analyzed using the SDS v2.1 software (Applied Biosystems). The second-round real-time PCR amplification was performed in a 96-well ABI PRISM 7900HT sequence detection system (Applied Biosystems) with the following steps: hold at $95^{\circ}$ for 10 min, 40 cycles at $95^{\circ}$ for $10 \mathrm{~s}, 60^{\circ}$ for $1 \mathrm{~min}$ and for the gp120 region, $60^{\circ}$ at $2 \mathrm{~min}$. The threshold was set based on negative controls where the first-round PCR product was omitted. The results were considered positive when the threshold cycle was $<35$ and there was an exponential increase in the normalized fluorescence intensity for five consecutive cycles. The identity of amplicons was verified by conducting melting-curve analysis with SybrGreen $\left(95^{\circ}\right.$ for $15 \mathrm{~s}, 30^{\circ}$ for $15 \mathrm{~s}, 95^{\circ}$ for $15 \mathrm{~s}$ at $10 \%$ ramp rate), which distinguished the expected PCR products from primer dimers of lower thermal stability. The meltingcurve analysis was a real-time PCR containing $2 \times$ TaqMan SybrGreen PCR Master Mix (Applied Biosystems) and similar amounts of inner primers and template as used in second-round real-time PCR except for the probes. The melting temperature $\left(\mathrm{T}_{\mathrm{m}}\right)$ of the duplexes was the maximum peak region obtained in the $-\mathrm{dRn} / \mathrm{Dt}$ versus temperature graph depicting melting curves. The 
Fig. 2. The $r t$ gene from sample Mnp97 was amplified and used in the MHAbce v.2 assay using probes designed from subtypes $\mathrm{C}, \mathrm{B}$ and $\mathrm{AE}$. The specific fluorescence $(\Delta R n)$ obtained was plotted against the number of cycles. $\Delta \mathrm{Rn}$ was observed with both the probes, subtype $C$ (1) and subtype $B$ (2). No specific fluorescence was detected with the probe for subtype AE (3). The horizontal line represents a threshold value based on negative controls.



Table 1. Determination of HIV-1 subtypes using MHAbce v.2 and HMA

\begin{tabular}{|c|c|c|c|c|c|c|c|c|c|c|c|c|c|c|c|c|c|c|c|c|c|c|}
\hline \multirow[t]{2}{*}{ Sample No. } & \multicolumn{8}{|c|}{ MHAbce } & \multirow{2}{*}{\multicolumn{2}{|c|}{$\begin{array}{l}\text { HMA } \\
\text { p24- C2- } \\
\text { p7 V3 }\end{array}$}} & \multirow{2}{*}{\multicolumn{2}{|c|}{ Sample No. }} & \multicolumn{8}{|c|}{ MHAbce } & \multicolumn{2}{|c|}{ HMA } \\
\hline & $p 17$ & pro & $r t$ & int & tat & $g p 120$ & Gp41 & $n e f$ & & & & & p17 & pro & $r t$ & int & tat & $g p 120$ & Gp41 & $n e f$ & $\begin{array}{l}\text { p24- } \\
\text { p7 }\end{array}$ & $\begin{array}{l}\text { C2- } \\
\text { V3 }\end{array}$ \\
\hline \multicolumn{9}{|l|}{ Subtype C } & & & \multicolumn{10}{|c|}{ Dual-probe reactivity } & & \\
\hline 1 Mnp6 & $\mathrm{C}$ & $\mathrm{C}$ & $\mathrm{C}$ & $\mathrm{C}$ & $\mathrm{C}$ & $\mathrm{C}$ & $\mathrm{C}$ & NR & $\mathrm{C}$ & $\mathrm{C}$ & 1 & Mnp24 & $\mathrm{C}$ & $\mathrm{C}$ & $\mathrm{B} / \mathrm{C}$ & $\mathrm{B} / \mathrm{C}$ & $\mathrm{C}$ & $\mathrm{C}$ & $\mathrm{C}$ & $\mathrm{C}$ & $\mathrm{C}$ & $\mathrm{C}$ \\
\hline $2 \mathrm{Mnp} 27$ & $\mathrm{C}$ & $\mathrm{C}$ & $\mathrm{C}$ & $\mathrm{C}$ & $\mathrm{C}$ & $\mathrm{C}$ & $\mathrm{C}$ & $\mathrm{C}$ & $\mathrm{C}$ & $\mathrm{C}$ & 2 & Mnp92 & $\mathrm{C}$ & $\mathrm{C}$ & $\mathrm{B} / \mathrm{C}$ & $\mathrm{C}$ & $\mathrm{C}$ & $\mathrm{C}$ & $\mathrm{C}$ & $\mathrm{C}$ & $\mathrm{C}$ & $\mathrm{C}$ \\
\hline $3 \mathrm{Mnp} 44$ & $\mathrm{C}$ & $\mathrm{C}$ & $\mathrm{C}$ & $\mathrm{C}$ & $\mathrm{C}$ & $\mathrm{C}$ & $\mathrm{C}$ & $\mathrm{C}$ & $\mathrm{C}$ & $\mathrm{C}$ & 3 & Mnp97 & $\mathrm{C}$ & $\mathrm{C}$ & $\mathrm{B} / \mathrm{C}$ & $\mathrm{C}$ & $\mathrm{C}$ & NR & $\mathrm{C}$ & $\mathrm{C}$ & $\mathrm{C}$ & B \\
\hline $4 \mathrm{Mnp} 47$ & $\mathrm{C}$ & $\mathrm{C}$ & $\mathrm{C}$ & $\mathrm{C}$ & $\mathrm{C}$ & $\mathrm{C}$ & NR & $\mathrm{C}$ & $\mathrm{C}$ & $\mathrm{C}$ & 4 & Mnp153 & B & NR & $\mathrm{B} / \mathrm{C}$ & B & NR & $\mathrm{B}$ & NR & NR & $\mathrm{B}$ & $\mathrm{B}$ \\
\hline 5 Mnp61 & $\mathrm{C}$ & $\mathrm{C}$ & $\mathrm{C}$ & $\mathrm{C}$ & NR & $\mathrm{C}$ & $\mathrm{C}$ & $\mathrm{C}$ & $\mathrm{C}$ & $\mathrm{C}$ & 5 & Mnp54 & $\mathrm{C}$ & NR & NR & NR & $\mathrm{C}$ & $\mathrm{B} / \mathrm{C}$ & NR & NR & $\mathrm{B}$ & $\mathrm{B}$ \\
\hline 6 Mnp91 & $\mathrm{C}$ & $\mathrm{C}$ & NR & $\mathrm{C}$ & $\mathrm{C}$ & $\mathrm{C}$ & $\mathrm{C}$ & $\mathrm{C}$ & $\mathrm{C}$ & $\mathrm{B}$ & & & & & & & & & & & & \\
\hline 7 Mnp96 & $\mathrm{C}$ & $\mathrm{C}$ & $\mathrm{C}$ & $\mathrm{C}$ & $\mathrm{C}$ & $\mathrm{C}$ & $\mathrm{C}$ & $\mathrm{C}$ & C & $\mathrm{C}$ & \multicolumn{10}{|c|}{ Multigenomic recombinants } & & \\
\hline 8 Mnp98 & $\mathrm{C}$ & $\mathrm{C}$ & $\mathrm{C}$ & $\mathrm{C}$ & $\mathrm{C}$ & NR & $\mathrm{C}$ & $\mathrm{C}$ & $\mathrm{C}$ & $\mathrm{B}$ & 1 & Mnp40 & $\mathrm{C}$ & $\mathrm{C}$ & $\mathrm{B}$ & $\mathrm{C}$ & $\mathrm{C}$ & $\mathrm{C}$ & NR & $\mathrm{B}$ & $\mathrm{C}$ & $\mathrm{C}$ \\
\hline 9 Mnp112 & $\mathrm{C}$ & $\mathrm{C}$ & $\mathrm{C}$ & $\mathrm{C}$ & $\mathrm{C}$ & $\mathrm{C}$ & $\mathrm{C}$ & $\mathrm{C}$ & $\mathrm{C}$ & $\mathrm{C}$ & 2 & Mnp68 & $\mathrm{C}$ & NR & NR & $\mathrm{C}$ & NR & $\mathrm{C}$ & B & $\mathrm{C}$ & $\mathrm{C}$ & $\mathrm{C}$ \\
\hline 10 Mnp126 & $\mathrm{C}$ & NR & $\mathrm{C}$ & $\mathrm{C}$ & NR & $\mathrm{C}$ & $\mathrm{C}$ & $\mathrm{C}$ & $\mathrm{C}$ & $\mathrm{C}$ & 3 & Mnp86 & $\mathrm{C}$ & $\mathrm{C}$ & $\mathrm{B}$ & $\mathrm{C}$ & NR & NR & $\mathrm{B}$ & $\mathrm{B}$ & $\mathrm{C}$ & $\mathrm{C}$ \\
\hline 11 Mnp129 & $\mathrm{C}$ & NR & $\mathrm{C}$ & $\mathrm{C}$ & $\mathrm{C}$ & $\mathrm{C}$ & $\mathrm{C}$ & $\mathrm{C}$ & $\mathrm{C}$ & $\mathrm{C}$ & 4 & Mnp89 & $\mathrm{C}$ & $\mathrm{C}$ & $\mathrm{C}$ & $\mathrm{B}$ & $\mathrm{C}$ & NR & $\mathrm{C}$ & $\mathrm{C}$ & $\mathrm{C}$ & $\mathrm{C}$ \\
\hline 12 Mnp137 & $\mathrm{C}$ & $\mathrm{C}$ & $\mathrm{C}$ & $\mathrm{C}$ & $\mathrm{C}$ & NR & $\mathrm{C}$ & $\mathrm{C}$ & $\mathrm{C}$ & $\mathrm{C}$ & 5 & Mnp90 & $\mathrm{C}$ & $\mathrm{AE}$ & $\mathrm{C}$ & $\mathrm{C}$ & $\mathrm{C}$ & NR & $\mathrm{C}$ & $\mathrm{C}$ & $\mathrm{C}$ & $\mathrm{C}$ \\
\hline 13 Mnp165 & NR & $\mathrm{C}$ & $\mathrm{C}$ & $\mathrm{C}$ & $\mathrm{C}$ & $\mathrm{C}$ & $\mathrm{C}$ & $\mathrm{C}$ & $\mathrm{C}$ & $\mathrm{C}$ & 6 & Mnp128 & $\mathrm{C}$ & $\mathrm{C}$ & NR & B & $\mathrm{B}$ & B & B & $\mathrm{C}$ & $\mathrm{C}$ & $\mathrm{B}$ \\
\hline 14 Mnp175 & $\mathrm{C}$ & $\mathrm{C}$ & $\mathrm{C}$ & $\mathrm{C}$ & $\mathrm{C}$ & NR & $\mathrm{C}$ & $\mathrm{C}$ & $\mathrm{C}$ & $\mathrm{C}$ & 7 & Mnp146 & $\mathrm{C}$ & $\mathrm{C}$ & $\mathrm{B}$ & $\mathrm{C}$ & NR & $\mathrm{C}$ & B & B & $\mathrm{C}$ & $\mathrm{C}$ \\
\hline 15 Mnp176 & $\mathrm{C}$ & $\mathrm{C}$ & $\mathrm{C}$ & $\mathrm{C}$ & $\mathrm{C}$ & $\mathrm{C}$ & $\mathrm{C}$ & $\mathrm{C}$ & $\mathrm{C}$ & $\mathrm{C}$ & 8 & Mnp154 & $\mathrm{C}$ & $\mathrm{C}$ & $\mathrm{C}$ & $\mathrm{C}$ & $\mathrm{C}$ & B & $\mathrm{C}$ & $\mathrm{C}$ & $\mathrm{C}$ & $\mathrm{B}$ \\
\hline \multicolumn{9}{|l|}{ Subtype B } & & & \multicolumn{10}{|c|}{ Multigenomic recombinants and dual-probe reactivity } & & \\
\hline 1 Mnp180 & B & B & B & B & NR & B & B & B & B & B & 1 & Mnp166 & $\mathrm{C}$ & $\mathrm{C}$ & B & $\mathrm{B} / \mathrm{C}$ & $\mathrm{C}$ & $\mathrm{C}$ & & $\mathrm{C}$ & $\mathrm{C}$ & B \\
\hline
\end{tabular}

Thirty samples were subjected to MHA using different probes, as depicted in figure 1 . The subtypes were determined on the basis of specific probe reactivity. Fifteen samples reacted with subtype $\mathrm{C}$ probes only; all the probes for subtype B reacted with one sample; 5 samples reacted with both the probes for subtypes B and C; 8 samples reacted with different subtype-specific probes, $\mathrm{B}, \mathrm{C}$ and $\mathrm{AE}$, indicating multigenomic variations; dual-probe reactivity and multigenomic variation were observed with one sample. The results of HMA for all the samples were also shown. NR = No probe reactivity. 
highest peak indicated the PCR product generated, with the lowest one pointing towards the primer dimers (data not shown). In order to validate this assay, the samples of known subtypes determined from DNA sequence analysis were included in MHA and no discrepancy was observed. Furthermore, assay performance was verified by sequencing of the samples after the MHA analysis. To rule out the possibility of cross-contamination, each TaqMan reaction was tested twice with the same primers and probes in separate plates at different times.

As revealed from MHAbce v. 2 results, 15 samples were of subtype C (Mnp6, Mnp27, Mnp44, Mnp47, Mnp61, Mnp91, Mnp96, Mnp98, Mnp112, Mnp126, Mnp129, Mnp137, Mnp 165, Mnp175 and Mnp176; table 1) and 1 sample was of subtype B (Mnp180; table 1). Dual-probe reactivity was found in 5 samples (Mnp24, Mnp92, Mnp97, Mnp153 and Mnp54), and a multigenomic recombination pattern in 8 samples (Mnp40, Mnp68, Mnp86, Mnp89, Mnp90, Mnp128, Mnp 146 and Mnp154), whereas 1 sample (Mnp166) showed both dual and multigenomic reactivity. Dual-probe reactivity occurred in reverse transcriptase and integrase genes. Here, the probes belonging to subtypes $\mathrm{B}$ and $\mathrm{C}$ for these genomic regions reacted equally in separate reactions. The dualprobe reactivity pattern of one such representative sample (Mnp97) in the $r t$ gene is shown in figure 2, where both the probes $\mathrm{C}$ and $\mathrm{B}$ had reacted equally, while the $\mathrm{AE}$ probe had no reactivity.
In summary, our data provide evidence for the possibility of new emerging strains of HIV-1 along with their dual infection among the IDU population from Manipur. The increasing number of recombinants documented so far shows that subtype distribution is a dynamic process and viruses that are already mosaic are likely to be transformed into further recombination events. In many samples, the occurrence of a $\mathrm{B} / \mathrm{C}$ recombination in gag, pol and env genes emphasized the presence of intragenomic recombinants. The sequence analysis of the full-length HIV-1 genome of these samples is in process to find out the recombination break points. In a few cases probe hybridization failed, which might be due to genetic diversity of HIV-1 within the clade, thus causing the hybridization of probes to heterotypic strains and decreasing the specificity, as described by others [12]. In conclusion, continuous monitoring of HIV-1 strains in this part of the country as well as characterization of emerging new recombinant forms is warranted, which might help in designing appropriate candidate HIV-1 vaccine.

\section{Acknowledgments}

We sincerely acknowledge the cooperation of Manipur State AIDS Control and Prevention in this study. We also thank the Department of Biotechnology, Government of India and Indian Council of Medical Research for financial support.

\section{References}

1 Chandrasekaran P, Dallabetta G, Loo V, Rao $\mathrm{S}$, Gayle H, Alexander A: Containing HIV/ AIDS in India: the unfinished agenda. Lancet Infect Dis 2006;6:508-521.

-2 Sarkar S, Mookherjee P, Roy A, Naik TN, Singh JK, Sharma AR: Descriptive epidemiology of intravenous heroin users - a new risk group for transmission of HIV in India. J Infect 1991;23:201-207.

-3 Weniger BG, Takebe Y, Ou CY, Yamazaki S: The molecular epidemiology of HIV in Asia. AIDS 1994;8:13-28.

-4 Aceijas C, Stimson GV, Hickman M, Rhodes T: Global overview of injecting drug use and HIV infection among injecting drug users. AIDS 2004;18:2295-2303.

5 Mandal DK, Jana S, Bhattacharya SK, Chakrabarti S: HIV-1 subtypes circulating in eastern and northeastern regions of India. AIDS Res Hum Retroviruses 2002;18:12191227.

-6 Bhanja P, Sengupta S, Sing NY, Sarkar K, Bhattacharya SK, Chakrabarti S: Determination of gag and env subtypes of HIV-1 detect- ed among injecting drug users (IDUs) in Manipur, India: evidence for intersubtype recombination. Virus Res 2005;114:149-153.

7 Lakhashe S, Tripathy S, Paranjape R, Bhattacharya J: Evidence of a novel B/C recombinant exhibiting unique breakpoints of near full-length HIV type 1 genome from Northeastern India. AIDS Res Hum Retroviruses 2008;24:229-234.

-8 Hierholzer J, Montano S, Hoelscher M, Negrete M, Hierholzer M, Avila MM, Carrillo MG, Russi JC, Vinoles J, Alava A, Acosta ME, Gianella A, Andrade R, Sanchez JL, Carrion G, Sanchez JL, Russell K, Robb M, Birx D, McCutchan FE, Carr JK: Molecular epidemiology of HIV type 1 in Ecuador, Peru, Bolivia, Uruguay, and Argentina. AIDS Res Hum Retroviruses 2002;18:1339-1350.

9 Hoelscher M, Dowling WE, Sanders-Buell E, Carr JK, Harris ME, Thomschke A, Robb ML, Birx DL, McCutchan FE: Detection of HIV-1 subtypes, recombinants, and dual infections in east Africa by a multi-region hybridization assay. AIDS 2002;16:2055-2064.
10 Kijak GH, SandersBuell E, Wolfe ND, Mpoudi-Ngole E, Kim B, Brown B, Robb ML, Birx DL, Burke DS, Carr JK, McCutchan FE: Development and application of a highthroughput HIV type 1 genotyping assay to identify CRF02_AG in West/West Central Africa. AIDS Res Hum Retroviruses 2004; 20:521-530

-11 Arroyo MA, Hoelscher M, Sateren W, Samkey E, Maboko L, Hoffmann O, Kijak GH, Robb M, Birx DL, McCutchan FE: HIV-1 diversity and prevalence differ between urban and rural areas in the Mebya region of Tanzania. AIDS 2005;19:1517-1524.

12 Kijak GH, Tovanabutra S, Sanders-Buell E, Watanaveeradej V, De Souza M, Nelson KE, Ketsararat V, Gulgolgarn V, Wera-arpachai M, Sriplienchan S, Khamboonrueng C, Birx DL, Robb M, McCutchan FE: Distinguishing molecular forms of HIV-1 in Asia with a high-throughput, fluorescent genotyping assay, MHAbce v.2. Virology 2007;358:178191. 